\title{
Autoridade enfraquecida, violência contra professores e trabalho pedagógico ${ }^{1}$
}

\section{Weakened authority, violence against teachers and pedagogical work}

\author{
Antônio Igo Barreto Pereira* \\ Antônio Álvaro Soares Zuin**
}

\begin{abstract}
RESUMO
Este artigo tem como objetivo analisar as ligações entre desautorização e violência escolar contra professores em uma instituição de educação básica e identificar seus possíveis efeitos no trabalho docente. Resultou de uma pesquisa com abordagem metodológica mista, delineamento exploratório e formato de estudo de caso. Foi realizada em uma escola pública estadual de ensino médio da cidade de Rio Branco (AC) no ano de 2015. A coleta de dados aconteceu em duas etapas: preliminar (levantamento documental) e principal (entrevista semiestruturada e questionário fechado). Os sujeitos foram 35 professores. A pesquisa procurou compreender a perspectiva dos sujeitos vitimados pela desautorização e pela violência. Os resultados indicam que os professores associam a violência, que dizem sofrer, ao enfraquecimento de sua autoridade, cujas consequências têm afetado diretamente seu desempenho profissional. Apesar de existir entre os professores um clima de insegurança e medo, ficou evidente que estes não são vítimas diretas de graves violações, mas de microviolências, entretanto, guiados por um imaginário da violência escolar, agem como se assim o fossem. Concluiu-se, portanto, que as falas dos professores sobre a desautorização e o aumento da violência revelam muito mais do que aparentam, simbolizam também uma denúncia da precarização do trabalho docente e do descaso com a educação; expressam, ainda, uma tentativa de significar suas angústias diante da
\end{abstract}

1 Pesquisa financiada pela Coordenação de Aperfeiçoamento de Pessoal de Nível Superior (CAPES) e pela Fundação de Amparo à Pesquisa do Acre (FAPAC).

* Universidade Federal do Acre. Programa de Pós-Graduação em Educação. Rio Branco, Acre, Brasil. E-mail: barretoigo@hotmail.com. https://orcid.org/0000-0003-2629-3094.

${ }^{* *}$ Universidade Federal de São Carlos. Programa de Pós-Graduação em Educação. São Carlos, São Paulo, Brasil. E-mail: dazu@ufscar.br. https://orcid.org/0000-0002-6850-2897. 
frustração profissional; representam, por fim, um recurso para justificar ou encobrir a desistência psicológica e física do trabalho.

Palavras-chave: Desautorização. Violência escolar. Trabalho pedagógico. Mal-estar docente.

\begin{abstract}
This article aims to analyze the connections between disempowerment and school violence against teachers in a basic education institution, as well as to identify its possible effects on the teaching work. It resulted from a research with mixed methodological approaches, exploratory delineation and a case study format. It was carried out in a public high school in the city of Rio Branco (AC), Brazil, in the year of 2015. The data collection occured in two stages: preliminary (documentary) and principal (semi-structured interview and closed questionnaire). The subjects were 35 teachers. The research sought to understand the perspective of the subjects victimized by the disempowerment and violence. The results indicate that teachers associate the violence, which they say they suffer, as a weakening factor of their authority, whose consequences have directly affected their professional performance. Although there is a climate of insecurity and fear among teachers, it is clear that they are not direct victims of serious violations, but of microviolences, nevertheless, guided by an imaginary of school violence, they act as if they were. It was concluded, therefore, that the teachers' talk about the disempowerment and the increase of the violence reveal much more than they seem, also symbolizing a denunciation of the precariousness of the teaching work and the neglection regarding education; additionally, they also express an attempt to signify their anguish in the face of professional frustration; and represent, finally, an appeal to justify or cover up the psychological and physical withdrawal of work.
\end{abstract}

Keywords: Disempowerment. School violence. Pedagogical work. Teacher malaise.

\title{
Introdução
}

O quadro de individualização e mecanização do homem moderno parece ter alterado profundamente as relações tradicionais entre o velho e o novo no mundo ocidental. Essa ideia é defendida por Arendt (2013) em Entre o passado e o futuro, com base, sobretudo, no argumento de que o declínio da autoridade 
está vinculado ao modo de vida instaurado pela modernidade. Nessa perspectiva, a grande importância e consideração social que historicamente eram devidas aos anciãos, em razão de suas experiências vividas e seus saberes acumulados, foi banalizada e convertida em rejeição, hostilidade e violência.

$\mathrm{Na}$ escola, por exemplo, como indica Arendt (2013), a crise da tradição tem custado muito caro, pois o ofício do professor guarda forte ligação com o passado, do qual tira os fundamentos e saberes essenciais a sua prática. Restariam, ao professor, poucas opções para continuar a ser o guardião da cultura e seu difusor aos mais jovens, diante de um mundo que supervaloriza o presente.

Ao considerar a proposição arendtiana de decadência das autoridades tradicionais, o quadro de aparente dificuldade no enfrentamento dos problemas comportamentais dos alunos, vivido atualmente pelas escolas, e a argumentação de que o aumento do desrespeito e da violência dos alunos está vinculado ao enfraquecimento da autoridade docente (o que, segundo os professores, vem causando grande mal-estar e dificuldade na concretização do processo de ensino e aprendizagem), o objetivo deste artigo é analisar as ligações existentes entre desautorização e violência escolar contra o professor em uma instituição de educação básica e avaliar seus possíveis efeitos no trabalho pedagógico.

A metodologia da pesquisa que serviu de base ao artigo foi de caráter misto (quantitativa e qualitativa), referenciada em Creswel (2010). Por meio desse método, foi levantado um número considerável de dados para o estudo, o que possibilitou suscitar diferentes aspectos e perspectivas do tema, informar possíveis contradições e realizar a confluência dos resultados obtidos. A pesquisa delineou-se como exploratória, com formato de estudo de caso. Segundo Lüdke e André (2014), essa modalidade de estudo oferece uma via extremamente fértil para compreender e reconhecer melhor as dificuldades da escola.

O campo utilizado para o estudo de caso foi uma escola pública estadual de ensino médio da cidade de Rio Branco (AC) que na época da pesquisa, em 2015, tinha um total de 1.196 alunos matriculados em 31 turmas, distribuídas nos três turnos ${ }^{2}$. Essa instituição foi indicada pela diretoria de gestão da Secretaria de Estado de Educação do Acre (SEE/AC) por ser afastada do centro da cidade e estar localizada numa região considerada perigosa, o que, segundo a diretoria, poderia ser interessante ao estudo.

A coleta de dados aconteceu em duas etapas: preliminar e principal. $\mathrm{Na}$ etapa preliminar, foram levantadas informações nos livros de registro das ocorrências. Na etapa principal, estabelecemos contato direto com os sujeitos da pesquisa, por meio da realização de entrevista semiestruturada com dez 
professores e questionários com perguntas fechadas e de múltipla escolha com 35 professores dos três turnos. Os dados quantitativos foram processados com o auxílio do programa Statistical Package for the Social Sciences (SPSS) e os dados qualitativos foram interpretados pelo método da Análise de Conteúdo proposto por Bardin (2011).

\section{A autoridade na relação professor-aluno}

O pensamento arendtiano que denuncia o esfacelamento da autoridade no mundo ocidental moderno, movido pela depreciação do passado e pelo rompimento da tradição, ganha força no discurso dos professores e torna-se uma das principais justificativas para as mudanças por que vem passando o magistério nos últimos tempos.

Os professores pesquisados neste estudo admitem que a autoridade dos tempos hodiernos não é a mesma do passado, e indicam que isso se deve, em grande medida, às transformações que aconteceram na sociedade, na família e na escola, principalmente por conta da democratização do acesso à informação, da ampliação dos direitos sociais e da globalização, que estabeleceu novos modos de viver e se relacionar.

Vive-se atualmente um momento bem diferente, os professores reconhecem. E não poderia ser diferente, pois os alunos são outros e têm outras necessidades, as relações mudaram, a vida se organiza de outras formas e as figuras de autoridade já não têm mais o mesmo sentido que antes. Por exemplo, se o aluno não percebe segurança e domínio na autoridade do professor, ou se observa algum tipo de abuso de poder e desrespeito, dificilmente obedecerá a suas ordens, muito pelo contrário, fará de tudo para tumultuar a aula e irritá-lo. Quando não concorda com o professor ou não gosta de suas aulas, não demora em manifestar resistência e insatisfação, de forma silenciosa ou mesmo explosiva. (SPÓSITO; GALVÃO, 2004; DAVIS; LUNA, 1991).

Nas circunstâncias atuais, ao que indicam os relatos, o professor com autoridade é aquele que sabe conquistar o desejo de aprender do aluno, que consegue trazê-lo para o seu lado. Mas para fisgar o desejo do aluno, é necessário ser transparente e deixar claro que está verdadeiramente comprometido e empenhado em ajudá-lo. Não pode haver dúvidas quanto às reais intenções, aos limites e às possibilidades do professor, para que não se criem falsas imagens ou expectativas exageradas, o que pode gerar frustração e mal-estar futuro na relação pedagógica. Dessa forma, o aluno perceberá o professor como alguém 
de confiança, em quem poderá depositar suas aspirações. Em assim sendo, a autoridade do professor será reconhecida e legitimada pelo aluno, como destacado no seguinte relato:

[...] Eles tinham uma aversão a mim, porque enquanto outros colegas da mesma escola conseguiam ser amados e no pátio e nos corredores eram abraçados e recebiam o maior carinho, eu não tinha isso. [...]. Eu conseguia ter domínio de sala, de conteúdo, mas não era bem visto pelos meus alunos. Foi então que eu coloquei um propósito: preciso ter domínio, mas eu preciso ter os alunos do meu lado; desde então eu estou sempre procurando isso. [...]. Percebi que são essas coisas assim que fazem com que você se aproxime deles e consiga ter autoridade quando precisa, porque eles sabem quando você os respeita, quando você fala direito com eles, com um tom de voz agradável $(\mathrm{P} 7)^{3}$.

Para conquistar o aluno e convencê-lo a renunciar a seus planos individuais em nome de um projeto coletivo, liderado por alguém que ele mal conhece, são requeridas outras condições igualmente importantes, como as explicitadas na seguinte fala:

[...] autoridade no sentido de saber ministrar, é como se fosse um grande maestro e líder ao mesmo tempo. Então, quando o professor demostra que domina o conteúdo, mesmo os alunos de escola pública, que não têm interesse etc., eles percebem, ai tu já tem $60 \%$. Quando você conversa com o aluno, respeitando ele como pessoa, na idade dele, conversando com ele como gente, tratando-o bem [...], já ganha mais 20\%. Despois é só você mostrar autoridade - "olha, agora é pra brincar, agora não é mais"-, estabelecer exatamente o momento que pode e o momento que não pode, exatamente os limites, e eles gostam [...] (P9).

Algumas ideias apresentadas no relato acima são recorrentes na fala de outros professores pesquisados. Uma delas é a de que o professor, para ter autoridade, precisa demonstrar domínio de sua área de conhecimento e saber

3 Com o objetivo de preservar a identidade dos sujeitos, os professores foram identificados no corpo do texto com a letra $\mathrm{P}$ e um número, de acordo com a ordem em que as entrevistas se sucederam (P1, P2, P3,..., P10). 
utilizar adequadamente as metodologias em que se apoia para ministrar as aulas. A junção desses dois predicados daria ao professor o reconhecimento do lugar que ocupa, como aquele que tem mestria, experiência teórico-metodológica naquilo que propõe ensinar. Isso lhe outorgaria parte da autoridade necessária para conduzir a classe (DAVIS; LUNA, 1991).

Outro pensamento que se manifesta nas falas dos professores é que as figuras de autoridade têm que demonstrar justiça, equilíbrio e transparência em seus comportamentos. Por estar na posição de comando, o professor deve contrabalançar seus posicionamentos e atitudes, a fim de criar um ambiente de convívio harmonioso em que seja possível compatibilizar as demandas individuais dos alunos com as necessidades coletivas da sala. Cabe ao professor ser dinâmico, flexível, lúdico, mas sem deixar de estabelecer regras e limites, e ser firme quando for preciso. Essa ideia se confirma entre os participantes de uma pesquisa coordenada por Spósito e Galvão (2004) sobre a vida de jovens estudantes do ensino médio de escolas públicas na cidade de São Paulo (SP).

Os professores que participaram dessa pesquisa destacam que os alunos, de maneira geral, gostam de professores com autoridade, pois consideram que estes são os que verdadeiramente levam a sério o que fazem e estão comprometidos com o processo de desenvolvimento e aprendizagem. Nesse caso, é como se o desejo de aprender do aluno se cruzasse com o desejo de ensinar do professor e os dois escolhessem caminhar numa mesma direção (SPELLER, 2004).

A importância da autoridade na formação dos mais jovens é destacada por Freud (2010) e Arendt (2013), ao defenderem que as novas gerações precisam ser orientadas pelos mais experientes, como pais e professores, para que preservem os bens culturais conquistados historicamente e as estruturas reguladoras da vida em coletividade, permitindo, portanto, a continuidade da civilização.

\section{Desautorização e violência contra o professor: aspectos determinantes}

De forma quase unânime, os professores apontam o contexto extraescolar como desencadeador da violência que ocorre na escola. Argumentam que os alunos apenas reproduzem o que vivem em seu dia a dia, por estarem inseridos em ambientes classificados como desestruturados e violentos, onde se presume que sejam frequentemente submetidos a desrespeitos e humilhações de todas as ordens, acabam assimilando esses comportamentos como padrões de conduta e utilizando-os em qualquer lugar ou circunstância. Por isso afirmam que a 
violência do aluno não é direcionada exatamente ao professor, mas que pode ser contra qualquer outra pessoa.

Não é exatamente com o professor, isso é uma reprodução da violência do convívio que ele já faz parte, é apenas uma externalização de algo que ele já vem trazendo. Então ele é chamado de palavrão na casa dele, ele vive na rua aprendendo com a vida o que tem de pior, ele tem uma família esfacelada, tem um nivel de renda muito baixo. Então o que ele traz pra cá é uma reprodução apenas. Inclusive nos finais de semana, que é o esfaqueamento, tiroteio, brigas [...] (P7).

Partem do princípio de que o aluno é moldado de acordo com as pressões externas à escola e que pouco ou nada poderiam fazer contra essa situação. Essa visão desconsidera a capacidade individual do aluno de interagir, significar e mudar os conteúdos sociais que internaliza e de intervir no ambiente de que faz parte. Essa postura pode também gerar graves preconceitos, pois se cria uma imagem negativa e um julgamento prévio dos alunos oriundos de lugares pobres, de bairros tidos como violentos, de escolas periféricas, por exemplo. Segundo Rêgo (1996), é comum entre os professores tratar a indisciplina e a violência

[...] como reflexo da pobreza e da violência presente de um modo geral na sociedade e fomentada, de modo particular, nos meios de comunicação, especialmente a TV. Nessa perspectiva, parecem compartilhar a ideia de que os alunos são o retrato de uma sociedade injusta, opressora e violenta, e a escola, por decorrência, vítima de uma clientela inadequada. [...] A escola se vê deste modo, impotente diante do aluno, principalmente dos que provêm de ambientes economicamente e culturalmente desfavorecidos (p. 88).

Os professores afirmam também que a família vem passando por grave crise e que isso tem interferido diretamente no desempenho da escola. Duas situações críticas são apresentadas: uma, em que os pais são excessivamente autoritários e violentos; outra, em que os pais não têm autoridade sobre os filhos (são altamente permissivos e não estabelecem limites); ambas, avaliadas como contraproducentes aos processos escolares. 
A questão da violência deles, a maioria é por parte da própria família. [...] quando a gente tem contato nem todos os pais estão dispostos, aliás, nem todos os pais se sentem pais, não sabem das suas obrigações de pais, principalmente referentes à escola. [...]. Então isso mostra o peso que exerce a estrutura familiar desse aluno, que se torna violento, que tem coragem de praticar uma violência, seja com colegas, seja com funcionários, seja com professor. Ele não tem noção de respeito, não tem noção de limites dentro da própria familia, dai ele externaliza [...] (P4).

Os depoimentos explicitam a influência do contexto familiar no comportamento dos alunos, mas são insuficientes para explicar os mal-estares da escola, como a desautorização e a violência. Isso porque a família apresenta problemas semelhantes aos da escola - incertezas em relação às mudanças socioeconômicas e culturais - e não tem o poder que os professores lhe imputam, pois os alunos também recebem influência de outros ambientes socializadores.

Se as reais causas do enfraquecimento da autoridade docente não são facilmente percebidas pelos professores, o mesmo não acontece com a identificação de seus efeitos, que ficam claramente explicitados, principalmente quando descrevem o tipo de relação dos alunos com a escola, considerado altamente hostil. Os tratamentos dispensados pelos alunos aos professores e demais funcionários são avaliados, pela maioria dos pesquisados, como grosseiros, desrespeitosos e violentos e semelhantes àqueles a que são submetidos pelos pais ou que demonstram em casa, com a família. Questionam o tempo todo a autoridade do professor, testam sua paciência ao extremo e se negam a obedecer às regras de convivência da escola.

Se com o professor o tratamento é considerado desrespeitoso e em algumas circunstâncias agressivo, com os colegas de sala parece ser ainda pior. Os professores relatam diversas situações de discussões e brigas violentas entre alunos dentro e fora da sala de aula. Os ataques vêm de todos os lados e de modo repentino. Uma simples brincadeira pode terminar em grave agressão. O que mais chama a atenção dos professores, e que os faz acreditar na influência do meio, é o fato de que esses conflitos, que quase sempre culminam com violência, não têm motivo aparente, são banais, gratuitos. Chamam a atenção também a forma covarde, cruel e insensível como muitas vezes tratam seus colegas e lidam com a violência. Os alunos dão a impressão de que não se compadecem com a dor do outro, ao contrário, parece que sentem prazer ao vê-lo sofrer. Conforme um dos depoimentos, 
Hoje é normal um menino brigando, tem uns que vão embora pra casa, tem outros que ficam em cima filmando [...]. Na minha época de escola, quando acontecia uma briga assim era coisa rápida. Aqui o que a gente percebe é que quanto mais se pede pra parar, mais elas ficam. [...] Me assusta porque é por bobagem, não tem motivo, é banal, são meninas, e elas gostam de ver o sangue. Para elas quanto mais sangue melhor. Parece que elas querem uma coisa muito próxima da morte. É uma grande fúria. E os demais ficam atiçando e filmando [...] (P9).

As cenas de violência gratuita entre alunos presenciadas na escola, aliadas ao discurso do aumento da violência e ao enfraquecimento da autoridade docente, ampliam a sensação de insegurança e medo no professor, que começa a se imaginar como vítima em potencial dos ataques repentinos dos alunos.

Não bastassem os comportamentos hostis e violentos, que surgem a qualquer momento, mesmo na presença do professor durante as aulas, os alunos parecem esboçar pouco ou nenhum interesse pelo que é trabalhado nas matérias. Por esse motivo, o professor se queixa de não conseguir concretizar seu planejamento e pôr em prática o que aprendeu e idealizou para seu trabalho. Apesar de todo o esforço empreendido, com atividades diversificadas e dinâmicas, afirma que dificilmente consegue fazer com que os alunos se concentrem e prestem atenção na aula. Dizem que os alunos raramente demonstram disposição para ouvir o que está sendo ensinado e para as atividades propostas; tratam a aula como algo sem importância. Por conta disso, demonstram apatia ou se distraem com conversas, brincadeiras e, principalmente, com o uso do aparelho celular, atual "febre" entre eles, como pode ser observado no seguinte relato:

$O$ desinteresse dos alunos é o que mais me incomoda. $O$ desinteresse vinculado à questão do celular. [...] tem salas, em particular, que você tira um ou dois e só, o resto termina a tarefa ou copia algo que tenha pra copiar, que começa, é rápido. Dizem: "professora já terminei". Ai pegam o celular e ficam horas. [...] é incrivel o desinteresse pela aula e o superinteresse pelo celular (P9).

A apatia e a falta de envolvimento do aluno na aula são apontados pelos professores como o fato que causa maior incômodo e desgaste na relação pedagógica, mais até que a desautorização e a violência escolar, como pode ser observado no gráfico 1 . 


\section{GRÁFICO 1 - OS INCÔMODOS DO PROFESSOR NO TRABALHO COM OS ALUNOS}

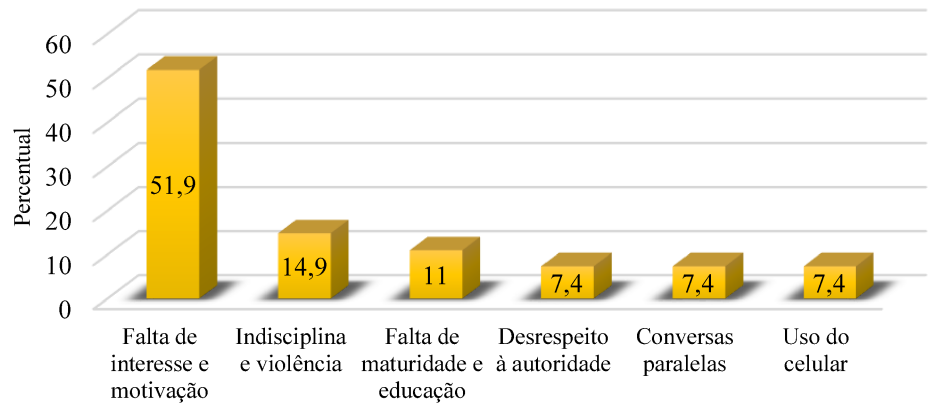

FONTE: Os autores (2016)

É possível que a apatia e o aparente descompromisso dos alunos em relação à aula incomodem tanto o professor pelo fato de confrontá-lo diretamente com seu insucesso profissional. É como se tais comportamentos simbolizassem a ineficácia de todos os investimentos e esforços empreendidos para superar as condições adversas enfrentadas na concretização do processo de ensino e aprendizagem. Representariam, afinal, a certificação de seu desprestígio e pouca importância, como anunciado pelo imaginário social.

Além dos potenciais fatores analisados acima, existem outros relacionados a própria profissão docente que podem ser determinantes à desautorização do professor e à violência contra ele. Como é de conhecimento comum, muitos candidatos à docência enfrentam sérios problemas já em seu processo formativo, primeiro, porque alguns não tinham intenção de ser professor, escolheram a licenciatura por falta de opção, o que, por si, já é motivo de desconforto e conflito interior, durante o curso (LAPO; BUENO, 2003). Segundo, porque não raro, recebem uma formação superficial e insuficiente para o exercício profissional (GATTI, 2009). Em outras palavras, antes mesmo de se dar conta do que o espera na escola e de começar a trabalhar, o professor pressente que deverá enfrentar obstáculos ligados à profissão.

Por conta disso, muitos professores desprestigiam sua profissão e se sentem envergonhados em exercê-la, reforçando o imaginário social negativo que já existe acerca da docência (ADORNO, 2011). Todavia, as duras consequências dessa escolha se evidenciam já no começo da carreira, quando percebem a complexidade do trabalho e a difícil realidade que enfrentarão. Como destaca uma professora, 
A maioria das pessoas que se formam em licenciatura vêm inclusive de escolas públicas, tentam a licenciatura por não ter coragem de tentar um outro curso. "Ah, esse aqui a concorrência é mais baixa, então eu vou pra cá". Primeiro começa errado aí, porque não é por vocação, não é por escolha. [...] só que quando você chega na sala de aula a pessoa se depara com uma situação [para a qual] ele não estava preparado, lidar com o filho dos outros, com o problema alheio. [...] a questão financeira acaba pesando, a estrutura também de trabalho é bem cruel, bem pesada e desestimula, então só com muito amor pra se continuar $(\mathrm{P} 4)$.

Se não bastasse a escolha profissional malograda, os processos formativos, na maioria, falhos e inadequados para o exercício da docência, as condições de trabalho que o professor encontra na escola também não são das melhores. Ainda por cima precisa se submeter a uma excessiva jornada de trabalho para complementar sua renda, que é muito baixa, sobrando pouco tempo para planejar as aulas e se dedicar à família. Essas condições ficam evidentes em diversos relatos, como este:

[...] muitos professores não têm tempo, porque hoje, para conseguir manter sua família, às vezes, tem que ter três empregos. Eu tenho dois contratos no Estado e ainda dou aula em uma universidade. Como é que eu vou ter tanto tempo assim pra me dedicar a metodologias? Às vezes não é má vontade do professor, é falta de tempo [...] (P2).

Os professores dizem também que mesmo trabalhando em condições precárias, precisam redobrar esforços para que os alunos não abandonem a escola, continuem interessados pelas aulas e consigam ser aprovados com boas notas. Revelam ainda que são pressionados a cumprir metas e atingir índices estabelecidos pelo sistema, que condiciona o repasse de verbas e as bonificações a esses resultados, os quais são amplamente divulgados nas mídias. Em tom de desabafo, os professores se dizem sobrecarregados e injustiçados por terem de assumir a maior parcela de responsabilidade da educação, em razão da ausência e da omissão da família e do Estado. Ainda mais quando não conseguem atingir as expectativas dos pais e do sistema, são considerados culpados pelo fracasso dos alunos e humilhados publicamente pela exposição dos pífios resultados das escolas.

[...] Se forem considerados [os] tempos passados, a cobrança do sistema é muito maior hoje sobre o professor. Então, para que a educação do 
estado tenha resultado, também a secretaria tem sistematizado muito mais as cobranças para que você consiga apresentar resultados [...]. Agora, você se depara com uma cobrança muito forte, tem que dividir com muita dificuldade sua familia e esses compromissos que tem que dar conta num tempo determinado, e com um acompanhamento muito perto [...] (P7).

Essa clara responsabilização dos professores pelos problemas da educação se evidencia quando afirmam que as principais estratégias utilizadas pela Secretaria de Educação centram-se na formação do professor e que questões como infraestrutura das escolas, condições de trabalho, financiamento da educação, valorização profissional, ficam em segundo plano. Por conta desse direcionamento, os professores são submetidos a uma exaustiva formação continuada, oferecida em horário diferente do trabalho, o que aumenta ainda mais sua jornada diária e seu desgaste físico e mental. Como desabafa uma professora:

Formações em cima de formações, quantas noites temos que estar aqui. Passamos o dia trabalhando e à noite temos que vir para um planejamento, pensar em uma solução para os problemas da escola, [...] mas nada é posto em prática. Então, esses cursos que nós fazemos é uma perda de tempo, porque nunca é feito nada. O que deveria ser pensado era mudar a infraestrutura da escola, enfim, era outra coisa, mas o sistema põe a culpa no professor, a culpa é sempre do professor, por isso ele faz curso, porque ele ach a que aperfeiçoando o professor vai resolver os problemas da educação [...] (P8).

Diante desse cenário nada promissor, $64,7 \%$ dos professores pesquisados declararam que, mesmo gostando do que fazem, mudariam de profissão caso tivessem outra oportunidade, e somente $35,3 \%$ permaneceriam na docência. Como profissões desejadas os professores indicam, em primeiro lugar, aquelas ligadas à área da saúde (medicina, psicologia e enfermagem), seguidas pelas profissões da área da administração pública (principalmente federal), por engenharia e arquitetura, pelo direito e, por fim, pela área da pesquisa. As profissões de desejo são as mais bem remuneradas, de maior prestígio social, dotadas de mais autonomia e liberdade. Essas informações demonstram claramente o desencantamento do professor com sua profissão.

Com formação na maioria das vezes inadequada, precárias condições de trabalho, baixa expectativa na carreira e pouco reconhecimento social, fica difícil ao professor sustentar sua autoridade e se manter respeitado pelos alunos. 


\section{Consequências da desautorização e da violência para o trabalho do professor}

Em seus relatos, os professores demonstram que se sentem abandonados pelas instâncias jurídica, administrativa (sistema educacional e escola) e familiar, as quais, no passado, legitimavam e davam suporte a suas decisões e práticas. "Já não existe o amparo do consenso social. Qualquer atitude do professor pode ser contestada, e haverá grupos e forças sociais dispostos a apoiar a contestação ao professor" (ESTEVE, 1999, p. 31).

No que diz respeito ao aspecto jurídico, os professores afirmam que a institucionalização do ECA tem garantido direitos importantes aos alunos, como estudar em uma escola pública e gratuita, mas também tem servido de prerrogativa e subterfúgio para que desrespeitem e agridam colegas de sala, professores e demais funcionários da escola pela certeza de impunidade. Alegam que, apesar das infrações, ameaças ou violências cometidas, a justiça garante ao aluno o direito de permanecer na mesma escola. Essa situação é relatada por um dos professores entrevistados:

[...] se um professor tira um aluno de sala de aula, porque está dando trabalho, ou porque respondeu, ou porque fez algo dentro da sala, o que acontece, muitas vezes? O próprio diretor, a própria instituição fala e o próprio ECA [Estatuto da Criança e do Adolescente] fala que o aluno tem o direito de ficar. Ai ele volta para a mesma sala de aula e continua fazendo as mesmas coisas e o aluno não é penalizado por isso, mas o professor é $[\ldots](\mathrm{P} 2)$.

Ao que indicam os depoimentos, o sistema educacional e a escola também não têm feito muito esforço para ajudar o professor, ao contrário, exigem que ele tenha domínio de sala e autoridade, mas, ao mesmo tempo, não lhe dão autonomia para tomar decisões. Além disso, são excessivamente indulgentes com os alunos, pois facilitam de todas as formas suas vidas e permitem que abusem dos limites estabelecidos sem nenhuma punição. Os professores se queixam também de exercer um falso poder sobre os alunos, pois a todo momento são solapados de seu lugar de autoridade na sala de aula, ora pelas pressões da lei, ora pelo próprio sistema educacional e pela escola.

A família, tal qual as demais instâncias, também se isenta de suas responsabilidades diante das demandas escolares, assim relatam os professores 
pesquisados. Afirmam que os pais deixaram, há um bom tempo, de acompanhar a vida escolar dos filhos e de tratar a escola e o professor com respeito. Quando solicitados a comparecer à escola, poucos atendem ao chamado, e os que a isso se dispõem, dificilmente aceitam reclamações ou pedidos de assistência. Esses pais tratam a escola como responsável absoluta pela educação dos seus filhos e a culpabilizam quando não obtêm o êxito esperado. O descompromisso da família e a responsabilização da escola se evidenciam em um dos registros dos Livros de Ocorrência da escola, datado de 4 de setembro de 2014:

O aluno T.R.S. $\left[2^{\circ} \text { ano - tarde }\right]^{4}$ foi encaminhado à direção porque "estava brincando" durante a aula da professora de Sociologia, A. C., e quando chamou sua atenção ficou rindo. O pai foi informado e disse que acreditava na versão do filho e que se a professora quisesse que ele comparecesse à escola "iria escutar o que não queria" e "que seu filho jamais foi à direção" e "que acreditava que a professora foi injusta com seu filho".

Sentindo-se desamparado pelas instâncias que deveriam resguardá-lo, o professor se diz vulnerável e temeroso na escola. Dos participantes da pesquisa, apenas $8,6 \%$ afirmam se sentir seguros na escola, $57,1 \%$ disse que em parte e $34,4 \%$ declarou que se sente totalmente inseguro.

Esses dados relacionados aos depoimentos dos sujeitos indicam que a insegurança e o medo no trabalho estão ligados principalmente à incerteza do que podem esperar dos alunos que, segundo os professores, na maioria das vezes, chegam à escola sem noções de moralidade, de limites e de regras sociais, que são violentos e tratam uns aos outros com grosseria e crueldade. Por conta disso, os professores acreditam que a qualquer momento podem ser vítimas de violência, como explicitado no seguinte depoimento:

[...] a maioria dos alunos que frequentam a escola ou usam drogas, ou não têm noção. São aquelas pessoas muito violentas, que não têm uma estrutura familiar; isso faz com que eles não tenham, assim, medo de fazer o mal a alguém. Eles não têm muito a perder com isso. É por isso que muitos professores se sentem inseguros ou até mesmo ameaçados. [...] É tenso você sair de casa sabendo que todo dia pode acontecer algo com você. Qualquer coisa pode acontecer (P3).

4 Para preservar a identidade do aluno foram grafadas apenas as iniciais de seu nome, seguidas pela série e turno em que estuda. 
Essa insegurança que produz medo está alicerçada no imaginário que os professores construíram acerca da violência escolar, baseado na ideia de que a escola está localizada em um lugar perigoso e de que a violência aumentou muito nos últimos tempos. Acredita-se que a escola, pelo fato de estar situada em bairro periférico - considerado lugar de grande incidência de crimes violentos, de tráfico e consumo de drogas, de vandalismo, de bebedeira -, sofreria inevitavelmente seus reflexos e apresentaria grande risco aos que lá trabalham.

Apesar dos dados indicarem que a maioria dos professores se sente insegura na escola, estudos como o de Spósito e Galvão (2004) e de Abramovay e Rua (2002) demonstram que não são os professores, e sim os alunos, as maiores vítimas da violência escolar. E de fato, dos professores participantes desta pesquisa, nenhum declarou ter sofrido violência grave, no caso, agressão física ou que coloque em risco a vida, e pouco mais da metade declarou já ter sofrido algum tipo de microviolência, como ofensas, ameaças, danos a pertences e furtos. Porém, quando indagados se tinham conhecimento de casos de violência (microviolências ou violência grave) contra professores, $100 \%$ deles responderam afirmativamente. Esses dados estão dispostos no gráfico 2.

\section{GRÁFICO 2 - TIPOS DE VIOLÊNCIA CONTRA O PROFESSOR}

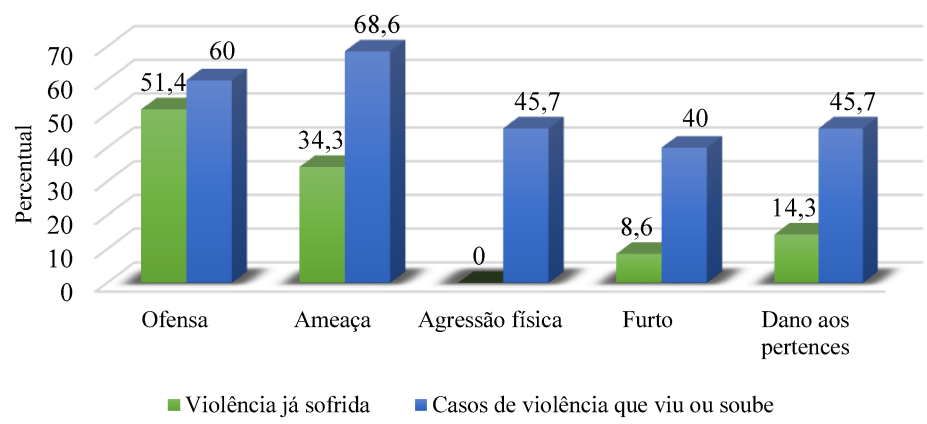

FONTE: Os autores.

Esses dados indicam que a imagem da escola violenta ou do aluno violento pode estar muito mais centrada no campo do discurso, produzido pela superdimensão que a fala da violência dá ao fenômeno, do que fundada na dimensão real dos fatos. Como pôde ser observado no gráfico 2 , os casos de violência são mais numerosos nas histórias sobre as quais o professor tem conhecimento (testemunhadas ou não) do que nas situações nas quais ele foi vitimado. 
No entanto, a espetacularização da violência e o boca a boca têm gerado grande sensação de medo e insegurança nas pessoas, para além dos reais perigos que elas correm (CALDEIRA, 2000). E, mesmo que não tenham sido vítimas diretas de violência, mudam seus comportamentos e hábitos para se defender do suposto mal que espreita em todos os lugares, a ponto de não se sentirem mais protegidos nem mesmo em ambientes tradicionalmente considerados seguros, como a escola (ESTEVE, 1999).

Por mais que, na maioria das vezes, essa sensação de insegurança e medo sejam apenas reflexos imagéticos dos rumores de que a escola vive momentos de grande caos e violência, seus efeitos na vida e no trabalho do professor são absolutamente reais. A esse respeito, alerta Esteve (1999):

Do problema que supõe o aumento da violência nas instituições de ensino, talvez o dado menos importante seja o de professores que sofrem diretamente uma agressão física. Deve-se contar com o efeito multiplicador desses acidentes, no plano psicológico, sobre os colegas ou amigos do professor agredido; e inclusive sobre outros professores, mas que recebem seu impacto através dos meios de comunicação social (p. 54).

A propagação de notícias de violência na escola, em seus arredores ou até mesmo em outros lugares do bairro, com a participação de alunos, aumenta ainda mais esse estado de tensão entre os professores, que, no ímpeto de se resguardar, acabam evitando a proximidade com os alunos. A título de exemplo, dos sujeitos pesquisados, $58,8 \%$ afirmam ter uma relação afetuosa com os alunos, mas com distanciamento.

Essa pouca proximidade na relação pedagógica, independente do sentido que assuma, constitui uma barreira e pode comprometer seriamente o estabelecimento e a sustentação dos laços afetivos transferenciais entre professor e aluno, tão importantes para o êxito do processo de ensino e aprendizagem (FREUD, 2012). O que era para garantir proximidade, confiança e afetividade se transforma em estranhamento, suspeição e hostilidade.

Outra grave consequência capaz de emergir da situação de instabilidade e medo do professor é a conversão da insegurança em preconceito contra os alunos, fundado na noção de que todos os alunos provenientes de bairros periféricos são violentos e pertencem a famílias "desestruturadas". Nessa circunstância, e na tentativa de se proteger, os professores passam a considerar seus alunos, de maneira indistinta, como perigosos em potencial, como ameaças iminentes. 
Apesar de os professores pesquisados não terem sido vítimas diretas de graves violações, a maioria deles, inclusive os que afirmam ainda manter certa autoridade, queixa-se de sofrer repetidas microviolências por parte dos alunos, o que tem se tornado um sério obstáculo à realização do seu trabalho nos últimos tempos. Suas reclamações parecem razoáveis, principalmente quando se consideram os indícios das consequências negativas geradas pelos desdobramentos e acúmulos das pequenas violências. Essa perspectiva é abordada nos estudos de Michaud (2001) sobre a violência ao considerar que os danos emocionais também são contabilizados nos prejuízos da violência, por afetarem diretamente a participação simbólica e cultural das vítimas no convívio social.

O clima de mal-estar e tensão resultante do desgaste profissional acaba por acionar no professor mecanismos psíquicos de defesa, como indica a perspectiva psicanalítica, que tentarão equilibrar, ou pelo menos diminuir, o sofrimento causado pela frustração do desejo não realizado. Como destacam Lapo e Bueno (2003, p. 78), "tentando livrar-se desse mal-estar, os professores assumem posturas defensivas que podem ir desde comportamentos agressivos, queixas constantes, críticas excessivas etc., até o distanciamento do ambiente, restringindo o convívio com os alunos".

Segundo Esteve (1999), outros recursos também são utilizados pelo professor para reduzir seu sofrimento e desviar-se dos problemas cotidianos no trabalho, como a inibição e o absentismo. Estes geralmente são os primeiros expedientes utilizados para reduzir as tensões do trabalho, o que pode culminar no abandono, ou mesmo no adoecimento. A inibição se materializa na despersonalização do trabalho docente e na relação superficial com o aluno. $\mathrm{O}$ professor torna-se rígido em suas falas e posições para bloquear qualquer envolvimento. $\mathrm{O}$ absentismo corresponde às pequenas fugas utilizadas para suspender, mesmo que de forma breve, as tensões do trabalho, por exemplo, com faltas, atestados médicos e licenças trabalhistas justificadas com argumentos simples.

O absentismo e a inibição correspondem, para Lapo e Bueno (2003), às formas de abandono parcial que antecedem ao abandono definitivo. Segundo as autoras, o abandono é um processo complexo, de duração longa, na maioria das vezes, e que envolve o acúmulo de uma série de elementos (descontentamentos, exaustão, descuido e depreciação do objeto abandonado). Seu desfecho ocorre com a demissão e o rompimento definitivo com o trabalho.

Quando os abandonos parciais não podem ser acionados, ou, quando utilizados, não surtem o efeito esperado, e o professor não pode abandonar em definitivo o emprego, seu sofrimento tende a aumentar. Então, esgotado física e emocionalmente, estressado e sem esperanças de melhorias, refugia-se na 
acomodação, isto é, numa espécie de inércia bloqueadora da energia laboral (LAPO; BUENO, 2003), que se manifesta na síndrome de Burnout ou no adoecimento físico (CODO, 1999). Para continuar trabalhando, muitos precisam recorrer a tratamentos psicoterápicos ou psiquiátricos, como pode ser observado no seguinte relato:

Eu tomo remédio pra dormir porque eu não estou conseguindo, o meu médico relutou muito, mas ele viu que não tinha jeito, eu estava sentindo dores no peito de estresse, [...]. O meu sono é aquele que todo tempo acorda, mas por quê? Porque é muita coisa durante o dia, aí eu não consigo relaxar (P9).

Quando percebe que o custo-benefício não é compensador e que conviver com os infortúnios da profissão parece algo insuportável, apesar dos inúmeros mecanismos de fuga acionados, muitos professores acabam abandonando em definitivo seu ofício, o que pode acontecer logo no início da carreira, ou depois de anos de tentativas malsucedidas (LAPO; BUENO, 2003; ESTEVE, 1999).

\section{Considerações finais}

A perspectiva admitida por Arendt (2013), de que a falência da autoridade na vida público/política havia atingido também a vida privada/pré-política da família e da escola, confirmou-se na fala dos professores pesquisados ao revelarem seus mal-estares no trabalho. Apontaram o aumento da violência sofrida por eles como uma clara evidência da deterioração da autoridade que teria reinado no passado - e à qual nostalgicamente se referem -, o que tem tornado a profissão de professor, em determinados lugares e situações, uma função extremamente difícil de ser cumprida.

Apesar de haver certo consenso, tanto no meio social quanto no educacional, de que a escola vive atualmente um momento crítico de aumento da violência, tornando-se um lugar perigoso para trabalhar, principalmente quando localizada em bairros periféricos, ficou evidente que os professores pesquisados não são vítimas diretas de graves violações, como as que atingem a integridade física ou põem em risco a vida, mas de microviolências (ofensas, desacatos, intimidações, desdéns e humilhações), porém agem como se assim o fossem: 
mudam suas rotinas, evitam proximidade com os alunos, criam preconceitos, tornam-se evasivos, endurecem suas práticas e se colocam em posição de defesa.

Por mais que as microviolências sejam pouco perceptíveis, de difícil mensuração e de menor peso aparente, nem por isso devem ser desconsideradas, pelos diversos efeitos que podem causar, a longo prazo, nos envolvidos, como, por exemplo, a sensação de impunidade nos perpetradores e o retraimento nas vítimas. Portanto, é necessário observar sua origem, extensão e recorrência, seus danos e sujeitos envolvidos, para que sejam feitos os devidos encaminhamentos em cada caso e se evitem consequências mais acintosas.

Todavia, a fala queixosa e enfática do professor sobre a decadência da autoridade e o aumento da violência, assim como a culpabilização da família e do meio em que os alunos vivem pelos problemas que ele enfrenta na escola, parecem revelar muito mais que uma simples constatação de incidências, de culpados ou de causas e efeitos perceptíveis. Os dados analisados na pesquisa indicam que essas reclamações relutantes:

- Expressam também uma espécie de denúncia da precarização da profissão docente e do descaso em relação à educação. Isso se mostra, por exemplo, quando se referiram à pouca procura pela carreira do magistério, às falhas nos processos formativos, aos baixos salários, à grande responsabilidade que lhes é atribuída, ao pouco prestígio que têm, à extensa jornada de trabalho que cumprem, ao curto tempo de que dispõem para planejamento, à escassez de materiais das escolas, à ineficiência do apoio pedagógico, à ausência da família e à grande pressão que sofrem para atingir as metas de aprovações e médias dos alunos.

- Representam ainda uma tentativa de significar suas angústias diante do fracasso dos investimentos emocionais no trabalho e da frustração em relação às expectativas profissionais não atendidas. Isso se mostra quando os professores admitiram que o pouco interesse dos alunos pelas aulas é o que mais lhes incomoda no trabalho educacional, até mais que a violência. A angústia também fica visível, por exemplo, quando os professores assumiram que, apesar de gostarem de seu ofício, mudariam de profissão por outra mais compensadora, caso tivessem oportunidade.

- Podem ser, além disso, um recurso para justificar ou encobrir sua desistência psicológica e física. Quando não têm condições de abandonar o trabalho em definitivo, os professores se refugiam no afastamento temporário, nas transferências ou remoções para outras escolas, na acomodação/Burnout, ou mesmo no adoecimento. Colocar-se no lugar de vítima é outra estratégia também muito utilizada para dimi- 
nuir o desconforto do sofrimento profissional, esse recurso serve para encobrir seu fracasso e para isentá-lo de obrigações e responsabilidades. Daí emergem, por exemplo, a indisposição para mudanças; o distanciamento nas relações pedagógicas; as posições irredutíveis, críticas e pessimistas em relação ao outro e ao trabalho.

\section{REFERÊNCIAS}

ABRAMOVAY, M.; RUA, M. G. Violências nas escolas. Brasília: UNESCO, 2002.

ADORNO, T. W. Educação e emancipação. Rio de Janeiro: Paz e Terra, 2011.

ARENDT, H. Entre o passado e o futuro. São Paulo: Perspectiva, 2013.

BARDIN, L. Análise de conteúdo. São Paulo: Edições 70, 2011.

CALDEIRA, T. P. R. Cidade de muros: crime, segregação e cidadania em São Paulo. São Paulo: Edusp/Ed. 34, 2000.

CODO, W. (Org.). Educação: carinho e trabalho. Petrópolis, RJ: Vozes, 1999.

CRESWELL, J. W. Projeto de pesquisa: métodos qualitativos, quantitativos e mistos. Porto Alegre: Artmed, 2010.

DAVIS, C.; LUNA, S. A questão da autoridade na educação. Cadernos de pesquisa. São Paulo, n. 76, p. 65-70, fev. 1991.

ESTEVE, J. M. O mal-estar docente: a sala de aula e a saúde dos professores. Bauru, SP: EDUSC, 1999.

FREUD, S. O mal-estar na civilização, novas conferências introdutórias e outros textos. (1930). São Paulo: Companhia das Letras, 2010. (Coleção Freud - Obras completas, vol. 18).

. Sobre a psicologia do colegial. In: Totem e Tabu, Contribuição à história do movimento psicanalítico e outros textos (1912-1914). (1914). São Paulo: Companhia das Letras, 2012. (Coleção Freud - Obras completas, vol.11).

GATTI, B. A. (Coord.). Professores do Brasil: impasses e desafios. Brasília: UNESCO, 2009.

LAPO, F. R.; BUENO, B. O. Professores, desencanto com a profissão e abandono do magistério. In: Cadernos de pesquisa, n. 118, p 65-88, mar./2003.

LÜDKE, M.; ANDRÉ, M. Pesquisa em educação: abordagens qualitativas. 2. ed. Rio de janeiro: E. P. U. 2014. 
MICHAUD, Y. A violência. São Paulo: Editora Ática, 2001.

RÊGO, T. C. R. A indisciplina e o processo educativo: uma análise na perspectiva vygotskiana. In: AQUINO, J. G. (Org.). Indisciplina na escola: alternativas teóricas e práticas. São Paulo: Summus, 1996.

SPELLER, M. A. R. Psicanálise e educação: caminhos cruzáveis. Brasília: Plano, 2004.

SPÓSITO, M. P.; GALVÃO, I. A experiência e as percepções de jovens na vida escolar na encruzilhada das aprendizagens: o conhecimento, a indisciplina, a violência. Perspectiva. Florianópolis, v. 22, n. 2, p. 345-380, jul./dez. 2004.

Texto recebido em 07 de fevereiro de 2019.

Texto aprovado em 08 de julho de 2019.

\section{Errata}

No artigo Autoridade enfraquecida, violência contra professores e trabalho pedagógico, com número de DOI: 10.1590/0104-4060.64821, publicado no periódico Educar em Revista, Curitiba, Brasil, v. 35, n. 76, p. 331-351, jul./ago. 2019, na página 331.

Onde se lia:

"*Boa Vista, Acre, Brasil."

Leia-se:

"*Rio Branco, Acre, Brasil." 